\title{
ESTIMASI JARAK GENETIK DAN FAKTOR PEUBAH PEMBEDA BEBERAPA BANGSA KAMBING DI SUMATERA UTARA MELALUI ANALISIS MORFOMETRIK
}

\section{Genetic Distance Estimation and Variable Differential Factor of Goat Breed in North Sumatra Through Morphometrics Analysis}

\author{
Heridianto Sibagariang ${ }^{1}$, Hasnudi ${ }^{2}$ dan Hamdan ${ }^{2}$ \\ 1. Mahasiswa Program Studi Peternakan Fakultas Pertanian Universitas SumateraUtara \\ 2. Staf Pengajar Program Studi Peternakan Fakultas Pertanian Universitas Sumatera Utara
}

\begin{abstract}
This studywas conducted to determinethe diversity morphometrics and estimation of genetic distance several breeds Goat (Boer, Boerka, Kacang, Muara and Samosir). This research was conducted at the Loka Penelitian Kambing potong, Sei-Putih (30 Boer goats,30 Boerka goats and 39 kacang goats), on Samosir (30 samosir goats) and on the Muara (30 Muara goats). The data collection was performed by measuring the shoulder height, hip height, body length, chest girth, chest dept, horns length, tail length, head length, head width, the width of the ear and earn length. The data obtained were processed with a simpled is criminant analysis using SAS program (Statistical Analysis System) and Dendogram use of the program MEGA (Molecular Evolutionary Genetics Analysis). The results of the analysis showed that the value of a phenotypically mixture Boer, Muara, and Samosir reached (100\%) (pure breed). Genetic distance between Boerka us Kacang $(4,74)$ and genetic distance between Samosir goat and Boer goat $(19,10)$. It is conclude that genetic distances showed the goats Boerka and Kacang have a close genetic distance, other wise the breeds Samosir goat and Boer goat has far genetic distance and variable differential factor morphology of the breed fifth goat is hip height, ear width, ear length and chest dept.
\end{abstract}

Keywords: Goat,genetic distance, morphometrics

\begin{abstract}
ABSTRAK
Penelitian ini dilakukan untuk mengetahui keragaman morfometrik dan estimasi jarak genetik beberapa bangsa kambing (Boer, Boerka, Kacang, Muara dan Kambing samosir). Penelitian ini dilakukan di Loka (30 ekor kambing Boer, 30 ekor kambing Boerka dan 39 ekor kambing Kacang), di Samosir (30 ekor kambing Samosir) dan di Muara (30 ekor Kambing Muara). Pengambilan data dilakukan dengan cara mengukur tinggi pundak, tinggi pinggul, panjang badan, lingkar dada, dalam dada, panjang tanduk, panjang ekor, panjang kepala, lebar kepala, lebar telinga dan panjang telinga. Data yang diperoleh diolah dengan analisis diskriminan sederhana dengan menggunakan Program dari SAS (Statistical Analysis System) dan Dendogram menggunakan program dari MEGA (Molekuler Evolusioner Genetic Analysis). Hasil analisis dari nilai campuran fenotifik menunjukkan bahwa Boer, Muara, dan Samosir adalah (100\%) kambing murni. Jarak genetik antara Boerka dan Kacang $(4,74)$ dan jarak genetik antara kambing Samosir dan kambing Boer $(19,10)$. Kesimpulan dari penelitian ini yaitu jarak genetik menunjukkan bahwa bangsa kambing boerka dan kacang memiliki jarak genetik yang dekat, sebaliknya bangsa kambing Samosir dengan bangsa kambing Boer memiliki jarak genetik yang jauh dan faktor peubah pembeda morfologi tubuh dari kelima bangsa kambing adalah tinggi pinggul, lebar telinga, panjang telinga dan dalam dada.
\end{abstract}

Kata kunci : Kambing, jarak genetik, morfometrik 


\section{PENDAHULUAN}

Berbagai jenis bangsa kambing yang ada di Indonesia di ketahui memiliki berbagai macam sifat-sifat kuantitatif yang sangat berbeda dan relatif seragam dengan bangsanya. Untuk dapat mengetahui jenis dan bangsa kambing tersebut salah satunya dari sifat-sifat kuantitatif nya.

Sifat-sifat yang diinginkan peternak adalah sifat yang bermanfaat atau menguntungkan, seperti daya produksi tinggi, jumlah dan bobot anakan saat lahir yang baik, pertumbuhan cepat, mortalitas rendah serta efisiensi penggunaan makanan yang tinggi. Produktivitas ternak ditingkatkan melalui perbaikan genetik dengan seleksi dan perkawinan serta melalui perbaikan lingkungannya (Lasley, 1978).

Salah satu metode perbedaan fenotip yang dapat dimanfaatkan untuk mengetahui jarak genetik adalah analisis keragaman.Pengukuran ukuran tubuh digunakan untuk membedakan keragaman baik ukuran maupun bentuk tubuh. Analisis keragaman dan korelasi banyak digunakan dalam mengkarakterisasi hubungan sifat-sifat fenotip dan genetik (Salako dan Ngere, 2002).

Salah satunya yang diperhatikan ialah faktor genetik, ternak yang memiliki hubungan kekerabatan yang dekat dapat diduga akan kecil peluangnya untuk meningkatkan heterosis dalam persilangannya. Oleh sebab itu sebelum melakukan perkawinan perlu diperhatikan jarak genetik antar ternak (Komenes, 1999).

Berdasarkan hal tersebut, penulis tertarik ingin melakukan sebuah penelitian berkaitan dengan faktor jarak genetik dan faktor dari peubah dari beberapa bangsa kambing yang ada di Sumatera Utara yaitu estimasi jarak genetik dan faktor peubah pembeda beberapa bangsa kambing melalui analisis morfometrik.

\section{BAHAN DAN METODE}

\section{Lokasi dan Waktu Penelitian}

Penelitian dilaksanakan di Loka Penelitian Kambing Potong, di Muara dan di Pangururan. Pada bulan Juni 2014.

\section{Bahan dan Alat}

Bahan yang digunakan adalah kambing Boer 30 ekor,Boerka 30 ekor, Kacang 39 ekor, Samosir 30 ekor,Muara 30 ekor. Pita ukur $(\mathrm{cm})$ dan tongkat ukur $(\mathrm{cm})$, alat tulis dan lembar data, laptop, perangkat lunak dari SAS (Statistical Analysis System) dan program MEGA (Molekuler Evolusioner Genetic Analysis). 


\section{Metode Penelitian}

Metode penelitian yang digunakan adalah analisis deskriptif dan diskriminan.

\section{Pengukuran Bagian Tubuh}

Bagian-bagian tubuh yang diukur antara lain:

1. Tinggi pundak diukur dengan menggunakan tongkat ukur.

2. Tinggi pinggul diukur dengan menggunakan tongkat ukur.

3. Panjang badan diukur dengan tongkat ukur.

4. Lingkar dada diukur menggunakan pita ukur.

5. Dalam dada diukur dengan menggunakan tongkat ukur.

6. Panjang ekor diukur dengan pita ukur.

7. Panjang Tanduk di ukur dengan pita ukur.

8. Panjang kepala (cm), diukur menggunakan pita ukur.

9. Lebar kepala (cm), diukur menggunakan pita ukur.

10. Panjang telinga $(\mathrm{cm})$, diukur dengan pita ukur.

11. Lebar telinga (cm), diukur dengan pita ukur (Blain, 1992).

\section{Analisis Data}

\section{Analisis Deskriptif}

Analisis deskriptif ditunjukkan untuk memperoleh karakterisasi ukuran-ukuran tubuh pada kambing. Metode ini dilakukan dengan menghitung nilai rataan (X), simpangan baku (s) dan koefisien keragaman (KK) dengan prosedur statistik berikut menurut Walpole (1982).

$$
\bar{X}=\sum_{i-1}^{n} x^{i} \quad \mathrm{~s}=\sqrt{\frac{\sum_{i-1}^{n}(x i-\bar{X})^{2}}{n}} \mathrm{kk}=-\stackrel{s}{-}(100 \%)
$$

Keterangan:

$\bar{X} \quad$ : rata-rata

$\mathrm{S} \quad:$ simpangan baku

Xi : ukuran ke-i dari peubah $\mathrm{x}$

$\mathrm{n} \quad$ : jumlah sampel yang diambil dari populasi

KK : koefisien keragaman

\section{Analisis Diskriminan}

Jarak genetik ditentukan dengan menggunakan analisis diskriminan sederhana $\left(\mathrm{D}^{2}\right)$. Analisis diskriminan dilakukan menggunakan peubah tinggi pundak, tinggi pinggul, panjang tanduk, panjang badan, lingkar dada, dalam dada, panjang ekor, panjang kepala, lebar kepala, panjang telinga dan lebar telinga. 


\section{Mahalanobis}

Jarak Mahalanobis adalah ukuran yang menyatakan jarak nilai setiap kasus dari ratarata seluruh kasus dan jarak genetik Mahalanobis sebagai ukuran jarak kuadrat genetik minimum yang digunakan sesuai petunjuk Nei (1987) adalah sebagai berikut :

$\mathbf{D}_{(\mathbf{i}, \mathbf{j})}^{2}=\left(\bar{X}_{\mathbf{i}}-\bar{X}_{\mathbf{i}}\right) \mathbf{C}^{-1}\left(\bar{X}_{\mathbf{i}}-\bar{X}_{\mathbf{i}}\right)$

Keterangan :

$\mathrm{D}_{(\mathrm{ij})}^{2}=$ Nilai Mahanolobis sebagai ukuran ja ladrat genetik antara kelompok kambing ke-i dan kelompok kambing ke-j .

$\mathrm{C}^{-1}==$ Kebalikan matrik gabungan ragam peragam antar peubah.

$\bar{X}_{\mathrm{I}}=$ Vektor nilai rataan pengamatan dari kelompok kambing ke-I pada masing-masing peubah kuantitatif, dan

$\bar{X}_{\mathrm{j}}=$ Vektor nilai rataan pengamatan darikelompok kambing ke-j pada masing-masing peubah kuantitatif,

Analisis statistik Mahalonobis dikerjakan menggunakan paket program SAS dengan prosedur PROC CANDISC dan PROC DISCRIM untuk menentukan penyebaran kambing dan nilai kesamaan diantara bangsa kambing Kumar dkk (2001).

\section{HASIL DAN PEMBAHASAN}

\section{Perbandingan Morfometrik Kambing Jantan}

Rataan dan simpangan baku ukuran tubuh ternak kambing jantan disajikan pada Tabel 1. Jumlah kambing jantan yang diamati adalah 29 ekor diantaranya kambing Boer 6 ekor, Boerka 5 ekor, Muara 5 ekor, Samosir 3 ekor dan Kacang 10 ekor. Hasil penelitian menunjukkan bahwa kambing Boer memiliki ukuran tubuh yang lebih besar dibandingkan dengan kambing Boerka, Muara, Samosir dan Kacang yaitu pada peubah panjang badan $(76,48 \pm 3,648 \mathrm{~cm})$, tinggi pundak $(71,23 \pm 36,476 \mathrm{~cm})$, lingkar dada $(83,81 \pm 6,782 \mathrm{~cm})$, dan panjang kepala $(21,48 \pm 0,974 \mathrm{~cm})$. Bangsa kambing jantan yang terkecil terdapat pada kambing Samosir kecuali pada ukuran lebar kepala $(12,33 \pm 0,450 \mathrm{~cm})$.

Koefisien keragaman pada bangsa kambing jantan disajikan pada Tabel 1. Hasil perhitungan koefisien keragaman menunjukkan bahwa ukuran tubuh jenis kambing Muara jantan memiliki keragaman terendah yaitu lingkar dada $(1,22)$ dan tertinggi terdapat pada dalam dada (2,35). Koefisien keragaman ukuran tubuh paling tinggi ditemukan pada jenis kambing jantan Boer yaitu panjang ekor $(3,24)$ dan tertinggi pada tinggi pinggul $(51,20)$. 
Tabel 1. Rataan simpangan baku, koefisien keragaman peubah kambing jantan (dewasa tubuh)

\begin{tabular}{|c|c|c|c|c|}
\hline Peubah & Jenis Kambing & $\bar{x} \pm \mathbf{s}(\mathbf{m m})$ & KK(\%) & \\
\hline \multirow[t]{5}{*}{ Panjang Badan } & Boer & $76,48^{A} \pm 3,64$ & 4,77 & \\
\hline & Boerka & $58,53^{\mathrm{D}} \pm 18,78$ & 32,09 & \\
\hline & Kacang & $71,28^{\mathrm{B}} \pm 2,73$ & 3,77 & \\
\hline & Muara & $68,08^{\mathrm{D}} \pm 1,23$ & 1,80 & \\
\hline & Samosir & $56,03^{\mathrm{D}} \pm 1,56$ & 2,78 & \\
\hline \multirow[t]{5}{*}{ Tinggi Pundak } & Boer & $67,41^{\mathrm{A}} \pm 3,54$ & 5,26 & \\
\hline & Boerka & $55,98^{\mathrm{B}} \pm 27,41$ & 48,96 & \\
\hline & Kacang & $57,90^{\mathrm{B}} \pm 0,95$ & 1,65 & \\
\hline & Muara & $65,68^{\mathrm{A}} \pm 1,24$ & 1,89 & \\
\hline & Samosir & $52,50^{\mathrm{C}} \pm 1,00$ & 1,90 & \\
\hline \multirow[t]{5}{*}{ Tinggi Pinggul } & Boer & $71,23^{\mathrm{A}} \pm 36,47$ & 51,20 & \\
\hline & Boerka & $58,28^{\mathrm{B}} \pm 26,71$ & 45,84 & \\
\hline & Kacang & $60,54^{\mathrm{B}} \pm 1,41$ & 2,34 & \\
\hline & Muara & $68,94^{\mathrm{A}} \pm 0,86$ & 1,25 & \\
\hline & Samosir & $54,83^{\mathrm{C}} \pm 1,15$ & 2,10 & \\
\hline \multirow[t]{5}{*}{ Lebar Telinga } & Boer & $9,43^{\mathrm{A}} \pm 0,70$ & 7,48 & Boerka \\
\hline & & $8,36^{\mathrm{B}} \pm 0,38$ & 4,59 & \\
\hline & Kacang & $6,17^{\mathrm{C}} \pm 0,27$ & 4,39 & \\
\hline & Muara & $9,16^{\mathrm{A}} \pm 0,40$ & 4,39 & \\
\hline & Samosir & $8,46^{\mathrm{A}} \pm 0,25$ & 2,96 & \\
\hline \multirow{5}{*}{ Panjang Telinga } & Boer & $22,70^{\mathrm{A}} \pm 1,56$ & 6,89 & \\
\hline & Boerka & $18,86^{\mathrm{B}} \pm 0,82$ & 4,34 & \\
\hline & Kacang & $12,24^{\mathrm{D}} \pm 1,38$ & 11,32 & \\
\hline & Muara & $34,47^{\mathrm{A}} \pm 9,87$ & 2,48 & \\
\hline & Samosir & $14,33^{\mathrm{C}} \pm 0,45$ & 3,14 & \\
\hline \multirow[t]{5}{*}{ Lebar Kepala } & Boer & $15,90^{\mathrm{A}} \pm 0,36$ & 2,31 & Boerka \\
\hline & & $16,04^{\mathrm{A}} \pm 0,63$ & 3,93 & \\
\hline & Kacang & $11,63^{\mathrm{C}} \pm 0,35$ & 2,86 & \\
\hline & Muara & $12,14^{\mathrm{B}} \pm 0,48$ & 2,85 & \\
\hline & Samosir & $12,33^{\mathrm{B}} \pm 0,45$ & 3,64 & \\
\hline \multirow[t]{5}{*}{ Panjang Kepala } & Boer & $21,48^{\mathrm{A}} \pm 0,97$ & 4,53 & \\
\hline & Boerka & $18,50^{\mathrm{B}} \pm 0,83$ & 4,50 & \\
\hline & Kacang & $14,15^{\mathrm{D}} \pm 0,80$ & 9,77 & \\
\hline & Muara & $15,92^{\mathrm{C}} \pm 0,45$ & 2,85 & \\
\hline & Samosir & $15,43^{\mathrm{C}} \pm 0,47$ & 3,05 & \\
\hline \multirow[t]{5}{*}{ Panjang Ekor } & Boer & $17,00^{\mathrm{A}} \pm 0,55$ & 3,24 & \\
\hline & Boerka & $14,28^{\mathrm{B}} \pm 1,77$ & 12,43 & \\
\hline & Kacang & $10,44^{\mathrm{C}} \pm 1,02$ & 9,77 & \\
\hline & Muara & $15,12^{\mathrm{B}} \pm 0,58$ & 3,89 & \\
\hline & Samosir & $9,56^{\mathrm{C}} \pm 0,87$ & 9,13 & \\
\hline \multirow[t]{5}{*}{ Lingkar dada } & Boer & $83,81^{\mathrm{A}} \pm 6,78$ & 8,09 & \\
\hline & Boerka & $78,52^{\mathrm{A}} \pm 6,61$ & 8,42 & \\
\hline & Kacang & $62,59^{\mathrm{C}} \pm 2,16$ & 3,46 & \\
\hline & Muara & $77,76^{\mathrm{B}} \pm 0,95$ & 1,22 & \\
\hline & Samosir & $63,83^{\mathrm{C}} \pm 3,42$ & 5,35 & \\
\hline \multirow[t]{5}{*}{ Dalam dada } & Boer & $33,98^{\mathrm{A}} \pm 2,10$ & 6,18 & \\
\hline & Boerka & $29,92^{\mathrm{B}} \pm 2,42$ & 8,08 & \\
\hline & Kacang & $22,40^{\mathrm{C}} \pm 1,46$ & 6,55 & \\
\hline & Muara & $32,38^{\mathrm{A}} \pm 0,76$ & 2,35 & \\
\hline & Samosir & $23,86^{\mathrm{C}} \pm 0,95$ & 3,98 & \\
\hline \multirow[t]{5}{*}{ Panjang Tanduk } & Boer & $21,31^{\mathrm{A}} \pm 1,75$ & 8,24 & \\
\hline & Boerka & $14,08^{\mathrm{B}} \pm 6,91$ & 49,10 & \\
\hline & Kacang & $13,63^{\mathrm{B}} \pm 1,83$ & 13,43 & \\
\hline & Muara & $6,58^{\mathrm{C}} \pm 1,01$ & 15,39 & \\
\hline & Samosir & $11,40^{\mathrm{B}} \pm 2,53$ & 22,23 & \\
\hline
\end{tabular}

Ket: Huruf superskrip yang berbeda pada peubah yang sama menyatakan berbeda nyata $(\mathrm{P}>0,05$. 


\section{Perbandingan Morfometrik Kambing Betina}

Rataan dan simpangan baku ukuran tubuh kambing betina disajikan pada Tabel 2. Jumlah kambing betina yang diamati adalah 130 ekor diantaranya kambing Boer 24 ekor , Boerka 25 ekor , Kacang 29 ekor, Muara 25 ekor dan Samosir 27 ekor. Hasil penelitian menunjukkan bahwa kambing Samosir memiliki ukuran tubuh yang lebih kecil dibandingkan kambing Boer dan Muara. Ukuran tubuh yang besar terdapat di kambing Muara betina yaitu sebesar $(75,42 \pm 1,293 \mathrm{~cm})$. Tetapi berbanding terbalik dengan ukuran kambing Boer yang hanya memiliki panjang badan $\quad(70,09 \pm 1,094 \mathrm{~cm})$ sedangkan memiliki tinggi pundak, tinggi pinggul dan lebar kepala lebih besar dari pada kambing Muara.

Koefisien keragaman pada jenis kambing betina disajikan pada Tabel 2. Hasil perhitungan koefisien keragaman menunjukkan bahwa ukuran tubuh jenis kambing Muara betina memiliki keragaman tertinggi pada panjang tanduk $(39,46 \%)$ dan terendah pada lingkar dada $(1,45 \%)$.

\section{Perbandingan Morfometrik Antar Jenis Kambing}

Rataan dan simpangan baku ukuran tubuh antar jenis Kambing ditampilkan pada Tabel 3. Jumlah keseluruhan kambing yang diamati adalah 159 ekor, diantaranya kambing Boer 30 ekor, kambing Boerka 30 ekor, kambing Kacang 39 ekor, kambing Muara 30 ekor dan kambing Samosir 30 ekor. Perbedaan dari kelima bangsa kambing tersebut dapat pada Tabel 3. Hasil penelitian menunjukkan bahwa bangsa kambing Samosir memiliki panjang badan yang paling kecil dibandingkan dengan kambing Boer, Boerka, Kacang dan Muara kecuali pada dalam dada $(25,74 \pm 0,962 \mathrm{~cm})$, dan lingkar dada $(66,38 \pm 3,511 \mathrm{~cm})$. Sedangkan ukuran panjang badan paling besar dimiliki oleh kambing Boer yaitu pada peubah panjang badan $(71,37 \pm 3,163 \mathrm{~cm})$, tinggi pundak $(62,98 \pm 3,529 \mathrm{~cm})$, tinggi pinggul $(66,54 \pm 3,467 \mathrm{~cm})$, lingkar dada $(80,05 \pm 4,750 \mathrm{~cm})$ dan panjang kepala $(17,36 \pm 2,215 \mathrm{~cm})$.

Perbandingan rataan yang diperoleh dari kedua jenis kambing tersebut menunjukkan bahwa adanya perbedaan kapasitas penyusun kerangka tubuh yang sebagian besar dipengaruhi dipengaruhi oleh faktor genetik dan faktor lingkungan walau kemungkinannya sangat kecil terjadi, sehingga dapat ditarik kesimpulan semakin besar ukuran kerangka tubuh suatu individu maka ukurannya tubuh juga akan besar menurut Soeparno (1992) yang menyatakan perbedaan komposisi tubuh diantara bangsa ternak terutama disebabkan oleh perbedaan ukuran tubuh dewasa. Faktor lingkungan dan genetik mempunyai hubungan yang erat untuk mengekspresikan kapasitas genetik individu secara sempurna diperlukan kondisi 
lingkungan yang ideal. Koefisien keragaman pada antar jenis Kambing ditampilkan pada Tabel 3.

Tabel 2. Rataan simpangan baku, koefisien keragaman peubah kambing betina(dewasa tubuh)

\begin{tabular}{|c|c|c|c|}
\hline Peubah & Jenis Kambing & $\bar{x} \pm \mathbf{s}(\mathbf{m m})$ & $\mathbf{K K}(\%)$ \\
\hline \multirow[t]{5}{*}{ Panjang Badan } & Boer & $70,09^{\mathrm{A}} \pm 1,09$ & 1,56 \\
\hline & Boerka & $59,74^{\mathrm{A}} \pm 2,73$ & 4,59 \\
\hline & Kacang & $57,22^{\mathrm{B}} \pm 4,00$ & 6,99 \\
\hline & Muara & $75,42^{\mathrm{A}} \pm 1,29$ & 1,71 \\
\hline & Samosir & $55,30^{\mathrm{B}} \pm 2,33$ & 4,22 \\
\hline \multirow[t]{5}{*}{ Tinggi Pundak } & Boer & $61,87^{\mathrm{A}} \pm 2,56$ & 4,14 \\
\hline & Boerka & $53,59^{\mathrm{C}} \pm 2,76$ & 5,15 \\
\hline & Kacang & $53,16^{\mathrm{C}} \pm 2,97$ & $\mathbf{5 , 5 9}$ \\
\hline & Muara & $57,08^{\mathrm{B}} \pm 2,99$ & 5,24 \\
\hline & Samosir & $50,07^{\mathrm{D}} \pm 2,87$ & 5,74 \\
\hline \multirow[t]{5}{*}{ Tinggi Pinggul } & Boer & $65,36^{\mathrm{A}} \pm 2,24$ & 3,43 \\
\hline & Boerka & $56,55^{\mathrm{C}} \pm 2,49$ & 4,41 \\
\hline & Kacang & $56,01^{\mathrm{C}} \pm 2,74$ & 4,42 \\
\hline & Muara & $59,75^{\mathrm{B}} \pm 2,92$ & 4,90 \\
\hline & Samosir & $52,85^{\mathrm{D}} \pm 2,62$ & 4,96 \\
\hline \multirow[t]{5}{*}{ Lebar Telinga } & Boer & $9,32^{\mathrm{A}} \pm 0.61$ & 6,62 \\
\hline & Boerka & $8,02^{\mathrm{C}} \pm 0,48$ & 6,04 \\
\hline & Kacang & $7,03^{\mathrm{D}} \pm 0,48$ & 4,39 \\
\hline & Muara & $8,88^{\mathrm{B}} \pm 0,77$ & 8,68 \\
\hline & Samosir & $7,80^{\mathrm{C}} \pm 0,53$ & 6,80 \\
\hline \multirow[t]{5}{*}{ Panjang Telinga } & Boer & $22,01^{\mathrm{A}} \pm 1,81$ & 6,89 \\
\hline & Boerka & $17,84^{\mathrm{B}} \pm 1,66$ & 6,94 \\
\hline & Kacang & $15,77^{\mathrm{D}} \pm 1,09$ & 6,94 \\
\hline & Muara & $16,66^{\mathrm{C}} \pm 0,93$ & 5,82 \\
\hline & Samosir & $13,38^{\mathrm{E}} \pm 0,90$ & 6,77 \\
\hline \multirow[t]{5}{*}{ Lebar Kepala } & Boer & $11,68^{\mathrm{A}} \pm 0,49$ & 4,21 \\
\hline & Boerka & $11,07^{\mathrm{C}} \pm 0,46$ & 4,23 \\
\hline & Kacang & $10,60^{\mathrm{D}} \pm 0,73$ & 6,92 \\
\hline & Muara & $11,75^{\mathrm{A}} \pm 0,38$ & 3,25 \\
\hline & Samosir & $11,39^{\mathrm{B}} \pm 0,55$ & 4,86 \\
\hline \multirow[t]{5}{*}{ Panjang Kepala } & Boer & $16,32^{\mathrm{A}} \pm 0,66$ & 4,05 \\
\hline & Boerka & $16,04^{\mathrm{A}} \pm 0,91$ & 5,67 \\
\hline & Kacang & $14,58^{\mathrm{B}} \pm 1,03$ & 7,11 \\
\hline & Muara & $14,90^{\mathrm{B}} \pm 0,49$ & 3,30 \\
\hline & Samosir & $14,99^{\mathrm{B}} \pm 0,57$ & 3,84 \\
\hline \multirow[t]{5}{*}{ Panjang Ekor } & Boer & $13,62^{\mathrm{A}} \pm 1,06$ & 7,82 \\
\hline & Boerka & $11,98^{\mathrm{B}} \pm 1,17$ & $\mathbf{9 , 8 1}$ \\
\hline & Kacang & $9,73^{\mathrm{D}} \pm 1,42$ & 4,66 \\
\hline & Muara & $11,38^{\mathrm{C}} \pm 0,73$ & 6,44 \\
\hline & Samosir & $9,62^{\mathrm{D}} \pm 0,67$ & 7,05 \\
\hline \multirow[t]{5}{*}{ Lingkar dada } & Boer & $79,11^{\mathrm{A}} \pm 3,71$ & 4,70 \\
\hline & Boerka & $69,22^{\mathrm{B}} \pm 4,28$ & 6,18 \\
\hline & Kacang & $63,37^{\mathrm{D}} \pm 5,81$ & 9,17 \\
\hline & Muara & $76,94^{\mathrm{A}} \pm 1,12$ & 1,45 \\
\hline & Samosir & $66,66^{\mathrm{C}} \pm 3,46$ & 5,19 \\
\hline \multirow[t]{5}{*}{ Dalam dada } & Boer & $30,62^{\mathrm{B}} \pm 1,31$ & 6,18 \\
\hline & Boerka & $27,35^{\mathrm{C}} \pm 1,46$ & 5,33 \\
\hline & Kacang & $26,67^{\mathrm{D}} \pm 2,34$ & 8,79 \\
\hline & Muara & $31,92^{\mathrm{A}} \pm 0,77$ & 2,44 \\
\hline & Samosi & $25,94^{\mathrm{D}} \pm 0,71$ & 2,76 \\
\hline \multirow{5}{*}{ Panjang Tanduk } & Boer & $13,99^{\mathrm{A}} \pm 2,42$ & 17,33 \\
\hline & Boerka & $10,40^{\mathrm{B}} \pm 3,72$ & 35,81 \\
\hline & Kacang & $7.08^{\mathrm{C}} \pm 2,74$ & 38,81 \\
\hline & Muara & $7,08^{\mathrm{C}} \pm 2,79$ & 39,46 \\
\hline & Samosir & $7,73^{\mathrm{C}} \pm 2,78$ & 36,02 \\
\hline
\end{tabular}

Ket: Huruf superskrip yang berbeda pada peubah yang sama menyatakan berbeda nyata $(\mathrm{P}>0,05$. $)$ 
Tabel 3. Rataan simpangan Baku, koefisien keragaman peubah antar kambing (dewasa tubuh)

\begin{tabular}{|c|c|c|c|}
\hline Peubah & Jenis Kambing & $\bar{x} \pm s(\mathbf{m m})$ & $\mathrm{KK}(\%)$ \\
\hline \multirow[t]{5}{*}{ Panjang Badan } & Boer & $65,08^{\mathrm{AB}} \pm 42,24$ & 64,91 \\
\hline & Boerka & $61,66^{\mathrm{AB}} \pm 5,12$ & 8,31 \\
\hline & Kacang & $57,55^{\mathrm{B}} \pm 3,60$ & 6,25 \\
\hline & Muara & $62,70^{\mathrm{A}} \pm 9,56$ & 15,24 \\
\hline & Samosir & $55,37^{\mathrm{B}} \pm 2,26$ & 4,08 \\
\hline \multirow[t]{5}{*}{ Tinggi Pundak } & Boer & $62,98^{\mathrm{A}} \pm 3,59$ & 5,60 \\
\hline & Boerka & $54,31^{\mathrm{C}} \pm 3,01$ & 5,55 \\
\hline & Kacang & $53,88^{C} \pm 3,13$ & 5,81 \\
\hline & Muara & $58,52^{\mathrm{B}} \pm 4,27$ & 7,29 \\
\hline & Samosir & $50,25^{\mathrm{D}} \pm 2,83$ & 5,64 \\
\hline \multirow[t]{5}{*}{ Tinggi Pinggul } & Boer & $66,54^{\mathrm{A}} \pm 3,46$ & 5,21 \\
\hline & Boerka & $57,22^{C} \pm 2,77$ & 4,85 \\
\hline & Kacang & $56,59^{C} \pm 2,87$ & $\mathbf{5 , 0 7}$ \\
\hline & Muara & $61,28^{\mathrm{B}} \pm 4,39$ & 7,17 \\
\hline & Samosir & $53,05^{\mathrm{D}} \pm 2,57$ & 4,85 \\
\hline \multirow[t]{5}{*}{ Lebar Telinga } & Boer & $9,34^{\mathrm{A}} \pm 0,62$ & 6,68 \\
\hline & Boerka & $8,08^{\mathrm{C}} \pm 0,48$ & 5,95 \\
\hline & Kacang & $6,81^{\mathrm{D}} \pm 0,58$ & 8,51 \\
\hline & Muara & $8,92^{\mathrm{B}} \pm 0,72$ & 8,74 \\
\hline & Samosir & $8,46^{\mathrm{A}} \pm 0,25$ & 2,96 \\
\hline \multirow[t]{5}{*}{ Panjang Telinga } & Boer & $22,15^{\mathrm{A}} \pm 1,76$ & 7,98 \\
\hline & Boerka & $18,01^{\mathrm{B}} \pm 1,59$ & 8,85 \\
\hline & Kacang & $14,86^{\mathrm{D}} \pm 1,94$ & 13,08 \\
\hline & Muara & $16,80^{\mathrm{C}} \pm 0,94$ & 5,85 \\
\hline & Samosir & $13,48^{\mathrm{C}} \pm 0,90$ & 6,73 \\
\hline \multirow[t]{5}{*}{ Lebar Kepalla } & Boer & $12,53^{\mathrm{A}} \pm 1,77$ & 14,16 \\
\hline & Boerka & $11,90^{\mathrm{B}} \pm 1,94$ & 16,33 \\
\hline & Kacang & $10,86^{\mathrm{C}} \pm 0,79$ & 7,32 \\
\hline & Muara & $11,82^{\mathrm{B}} \pm 0,41$ & $\mathbf{3 , 5 3}$ \\
\hline & Samosir & $11,49^{\mathrm{B}} \pm 0,60$ & 5,30 \\
\hline \multirow[t]{5}{*}{ Panjang Kepala } & Boer & $17,36^{\mathrm{A}} \pm 2,21$ & 12,75 \\
\hline & Boerka & $16,45^{\mathrm{B}} \pm 1,28$ & 7,80 \\
\hline & Kacang & $14,47^{\mathrm{C}} \pm 0,99$ & 6,85 \\
\hline & Muara & $15,07^{\mathrm{C}} \pm 0,61$ & 4,08 \\
\hline & Samosir & $15,04^{\mathrm{C}} \pm 0,57$ & 3,28 \\
\hline \multirow[t]{5}{*}{ Panjang Ekor } & Boer & $14,30^{\mathrm{A}} \pm 1,68$ & 11,76 \\
\hline & Boerka & $12,36^{\mathrm{B}} \pm 1,52$ & 12,36 \\
\hline & Kacang & $9,91^{\mathrm{C}} \pm 1,35$ & 13,70 \\
\hline & Muara & $12,01^{\mathrm{B}} \pm 1,57$ & 13,14 \\
\hline & Samosir & $9,61^{\mathrm{C}} \pm 0,68$ & 7,09 \\
\hline \multirow[t]{5}{*}{ Lingkar dada } & Boer & $80,05^{\mathrm{A}} \pm 4,75$ & 5,93 \\
\hline & Boerka & $70,77^{\mathrm{C}} \pm 5,73$ & 8,09 \\
\hline & Kacang & $63,17^{\mathrm{E}} \pm 5,11$ & 8,09 \\
\hline & Muara & $77,08^{\mathrm{B}} \pm 1,12$ & 14,56 \\
\hline & Samosir & $66,38^{\mathrm{D}} \pm 3,51$ & 5,28 \\
\hline \multirow[t]{5}{*}{ Dalam dada } & Boer & $31,29^{\mathrm{A}} \pm 2,00$ & 6,39 \\
\hline & Boerka & $27,78^{\mathrm{B}} \pm 1,87$ & 6,75 \\
\hline & Kacang & $25,60^{\mathrm{C}} \pm 2,18$ & 8,51 \\
\hline & Muara & $31,99^{\mathrm{A}} \pm 0,78$ & 2,44 \\
\hline & Samosir & $25,74^{\mathrm{C}} \pm 0,96$ & 3,73 \\
\hline \multirow[t]{5}{*}{ Panjang Tanduk } & Boer & $15,45^{\mathrm{A}} \pm 3,75$ & 24,28 \\
\hline & Boerka & $11,01^{\mathrm{B}} \pm 4,47$ & 40,64 \\
\hline & Kacang & $8,76^{\mathrm{C}} \pm 3,83$ & 43,81 \\
\hline & Muara & $7,00^{\mathrm{C}} \pm 2,58$ & 36,87 \\
\hline & Samosir & $8,10^{\mathrm{C}} \pm 2,94$ & 36,30 \\
\hline
\end{tabular}

Ket: Huruf superskrip yang berbeda pada peubah yang sama menyatakan berbeda nyata $(\mathrm{P}>0,05$. $)$ 
Koefisien keragaman pada bangsa kambing disajikan pada Tabel 3. Hasil penelitian menunjukkan keragaman yang lebih tinggi dari masing-masing peubah atau lebih dominan tidak seragam terdapat pada kambing Boer yaitu panjang badan $(64,91 \%)$, tinggi pundak $(5,60 \%)$, tinggi pinggul $(5,21 \%)$, lebar telinga $(6,68 \%)$, panjang telinga $(7,98 \%)$ lingkar dada $(5,93 \%)$ dan lebar kepala $(14,16)$. Keragaman sifat morfologi dapat terjadi karena adanya proses seleksi (alam dan buatan), perkawinan silang atau bencana alam yang dapat berakibat hilang atau hanyutnya gen tertentu (Anderson 2001).

Keragaman yang lebih rendah dari keempat bangsa terdapat pada bangsa Kambing Samosir yaitu panjang badan (4,08\%), tinggi pundak (1,99\%), tinggi pinggul $(4,85 \%)$, panjang telinga $(6,73 \%)$, lebar kepala $(5,30 \%)$, panjang kepala $(3,28 \%)$ dan dalam dada $(3,73 \%)$. Ukuran tubuh bangsa kambing Boer dengan Boerka secara umum lebih seragam pada dalam dada $(6,39 \%$ dengan $6,75 \%)$ dan Boerka dengan Samosir pada ukuran tinggi pinggul (4,85\% dengan $4,85 \%)$.

\section{Peubah Pembeda Bangsa Kambing}

Tabel 4 disajikan total struktu: nonik bangsa kambing, yang merupakan analisis diskriminan. Gunawan dan Sumantri (2008) menyatakan analisis diskriminan juga dipakai untuk menentukan beberapa peubah dari ukuran fenotipik yang memiliki pengaruh kuat terhadap penyebab terjadinya pengelompokan ternak (pembeda kelompok).

Berdasarkan hasil analisis kanonikal dapat diketahui peubah-peubah ukuran tubuh yang memberi pengaruh kuat yang membedakan antar bangsa Kambing adalah lebar pinggul $(0,84)$, panjang telinga $(0,94)$ pada $\mathrm{KAN}-1$, lebar telinga $(0,50)$, dalam dada $(0,56)$ pada KAN-2. Pendugaan tersebut didasarkan pada tingginya nilai kanonikal dari peubah lebar pinggul, panjang telinga, lebar telinga dan dalam dada.

\section{Nilai Kesamaan dan campuran antar Bangsa Kambing}

Presentase nilai kesamaan dan campuran kambing ditampilkan pada Tabel 5. Nilai tersebut menjelaskan proporsi nilai campuran yang mempengaruhi kesamaan antar jenis kambing denga jenis lainnya berdasarkan ukuran morfometrik.

Kesamaan ukuran morfometrik antar bangsa kambing dari tinggi ke yang rendah berturutturut adalah kambing Boer (100\%), Muara (100\%), Samosir (100\%), Kacang (87,18\%), Boerka (86,67\%). Hasil analisis menunjukkan Kambing Boer, Muara, dan samosir tidak 
tercampur dengan Kambing lain (100\%) (pure breed). Fenotifik paling rendah adalah kambing Boerka $(86,67 \%)$ yang dipengaruhi oleh dua jenis kambing Boer dan Kacang. Sehingga menujukkan kemurnian dari bangsa kambing Boerka sangat rendah.

Bangsa kambing Boer, Muara dan Samosir memiliki kesamaan fenotifik tertinggi yaitu (100 \%) (pure breed). Tingginya kesamaan kambing Boer, Muara dan Samosir dipengaruhi oleh faktor lingkungan dataran tinggi dan genetik.

Tabel 4. Total struktur kanonikal bangsa kambing (Boer, Boerka, Kacang, Muara dan Samosir).

\begin{tabular}{llr}
\hline Variable Ukuran Tubuh & KAN1 & KAN2 \\
\hline Panjang Badan & 0.158840 & 0.186104 \\
Tinggi Pundak & 0.811869 & 0.138920 \\
Tinggi Pinggul & $\mathbf{0 . 8 4 5 6 2 8}$ & 0.123233 \\
Lebar Telinga & 0.699030 & $\mathbf{0 . 5 0 2 7 7 8}$ \\
Panjang Telinga & $\mathbf{0 . 9 4 7 1 0 5}$ & -0.102707 \\
Lebar Kepala & 0.372031 & 0.114273 \\
Panjang Kepala & 0.586597 & -0.129289 \\
Panjang Ekor & 0.816472 & 0.063261 \\
Lingkar Dada & 0.775742 & 0.438321 \\
Dalam Dada & 0.735546 & $\mathbf{0 . 5 6 9 9 7 8}$ \\
Panjang Tanduk & 0.552344 & -0.352034 \\
\hline
\end{tabular}

Tabel 5. Persentase kesamaan fenotifik dalam bangsa dan antar bangsa Kambing (Boer, Boerka, Kacang, Muara dan Samosir).

\begin{tabular}{lrccccc}
\hline Bangsa Kambing & \multicolumn{1}{c}{ Boer } & \multicolumn{1}{c}{ Kacang } & Muara & Samosir & Boerka & Total \\
\hline Boer & $\mathbf{1 0 0 , 0 0}$ & 0,00 & 0,00 & 0,00 & 0,00 & 100,00 \\
Kacang & 0,00 & $\mathbf{8 7 , 1 8}$ & 0,00 & 0,00 & 12,82 & 100,00 \\
Muara & 0,00 & 0,00 & $\mathbf{1 0 0 , 0 0}$ & 0,00 & 0,00 & 100,00 \\
Samosir & 0,00 & 0,00 & 0,00 & $\mathbf{1 0 0 , 0 0}$ & 0,00 & 100,00 \\
Boerka & 3,33 & 6,67 & 0,00 & 3,33 & $\mathbf{8 6 , 6 7}$ & 100,00 \\
\hline
\end{tabular}

\section{Peta Penyebaran Bangsa Kambing}

Peta penyebaran antar kambing berdasarkan hasil analisis pada Gambar 1 memperlihatkan bangsa kambing Boer dominan mengelompok ke sebelah kanan bawah aksis X. Hal ini memperlihatkan penampilan fenotifik dari kambing boer lebih dominan pada panjang badan, tinggi pinggul, tinggi pundak, dalam dada, lingkar dada, panjang kepala, lebar kepala serta panjang ekor yang berbeda dibandingkan dengan bangsa kambing lainnya walaupun terdapat menyebar ke sebelah kanan atas aksis Y dan bangsa kambing Muara mengelompok lebih dominan kesebelah kanan atas aksis Y karena pada panjang badan, tinggi pinggul, tinggi pundak, dalam dada, lingkar dada, panjang kepala, lebar kepala serta panjang ekor yang berbeda dengan kambing kacang, boerka dan samosir. Kemudian bangsa kambing samosir juga mengelompok lebih dominan ke sebelah kiri atas aksis $\mathrm{Y}$ walaupun terdapat kerumunan bangsa kambing kacang. Karena adanya kesamaan yang dimiliki antar kambing 
tersebut dari kedua morfometrik yang ada pada kambing. Begitu juga bangsa kambing kacang mengelompok ke sebelah kiri bawah aksis X terdapat kerumunan bangsa Boerka. Hal ini dikarenakan adanya persamaan morfometrik dan juga fenotifik dari kedua bangsa kambing tersebut

Peta penyebaran kelompok bangsa kambing menggambarkan bahwa bangsa Kambing Boer memiliki ukuran tubuh yang berbeda atau jarak yang jauh dengan bangsa kambing Samosir, begitu juga dengan bangsa kambing Muara dengan bangsa kambing Samosir, sedangkan bangsa kambing Boerka dengan bangsa kambing Kacang kerumunannya berdekatan sehingga diduga terdapat beberapa kesamaan fenotifiknya.

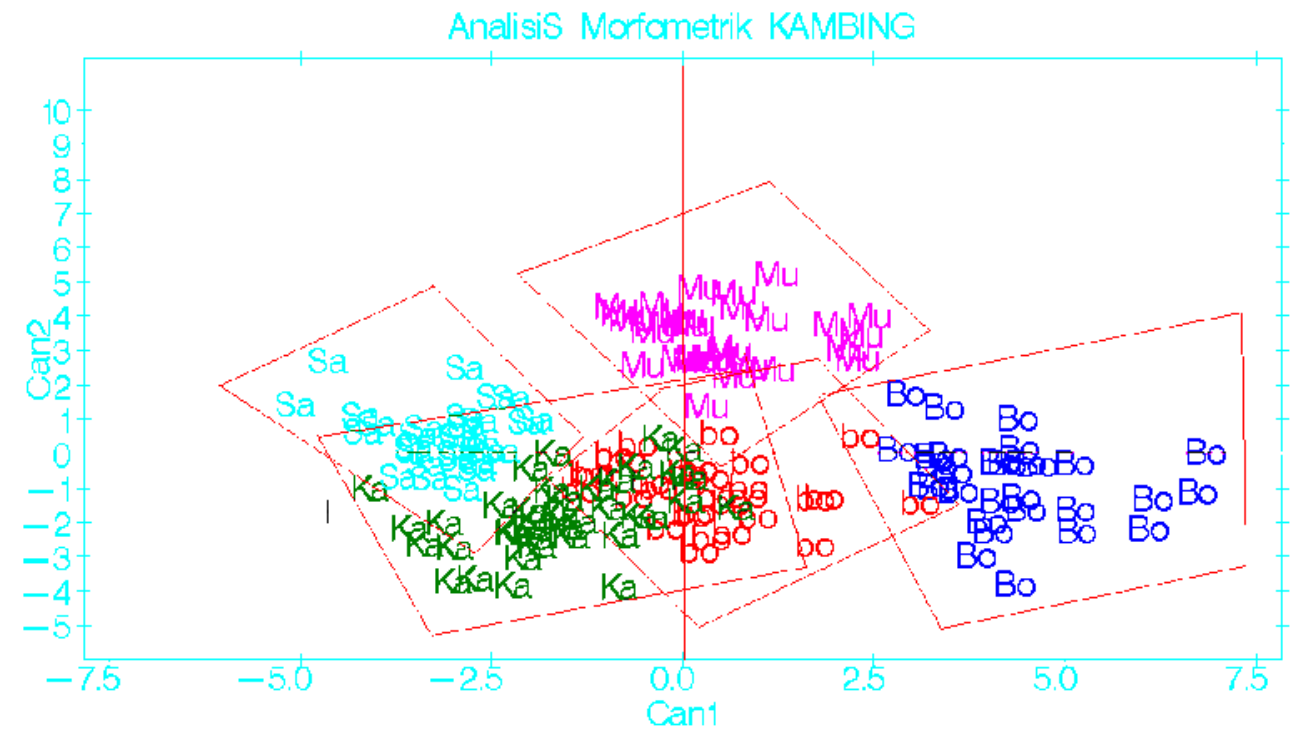

Keterangan: Bo : Boer.bo :Boerka. Ka: Kacang. Mu : Muara Sa: Samosir

Gambar 1. Plot kanonikal penyebaran bangsa kambing

Tabel 6. Matriks jarak genetik bangsa kambing.

\begin{tabular}{llllll}
\hline Bangsa kambing & Boer & Kacang & Muara & Samosir & Boerka \\
\hline Boer & 0 & & & & \\
Kacang & 38,54652 & 0 & & & \\
Muara & 33,89305 & 32,63096 & 0 & & \\
Samosir & $\mathbf{5 8 , 0 9 1 0 8}$ & 14,37015 & 26,19087 & 0 & \\
boerka & 17,59723 & $\mathbf{9 , 4 8 1 8 7}$ & 23,46394 & 16,51984 & 0 \\
\hline
\end{tabular}




\section{Penentuan Estimasi Jarak Genetik dan Dendogram antar Bangsa Kambing}

Nilai matrik jarak antar masing-masing bangsa kambing dapat dilihat pada Tabel 6, nilai tersebut didapat dari hasil analisis diskriminan yang menghasilkan kuadrat jarak antar bangsa kambing yang diamati.

Penentuan jarak genetik berdasarkan karakteristik ukuran tubuh menunjukkan jarak terdekat ditemukan antara bangsa kambing Boerka dengan bangsa Kambing Kacang yaitu sebesar 9,48. Jarak genetik terjauh ditemukan antara bangsa Kambing Samosir dengan bangsa kambing Boer sebesar 58,09. Untuk melihat gambaran kedekatan dan gambaran terjauh antar bangsa kambing diatas dapat dilihat pada dendogram jarak genetik.

Dendogram yang ditampilkan pada Gambar 2 diperoleh dari matriks jarak genetik pada Tabel 6. Dendogram menunjukkan bahwa kambing Boerka dan Kacang memiliki hubungan kekerabatan yang dekat sehingga bila terjadi persilangan antara Kambing Boerka dan Kacang tidak akan memberikan perkembangan kuantitatif yang signifikan. Jenis kambing yang memiliki hubungan kekerabatan terjauh adalah kambing Boer, hal ini karena kambing Boer adalah kambing murni bukan persilangan dan bukan kambing asli indonesia melainkan kambing asli Afrika Selatan.

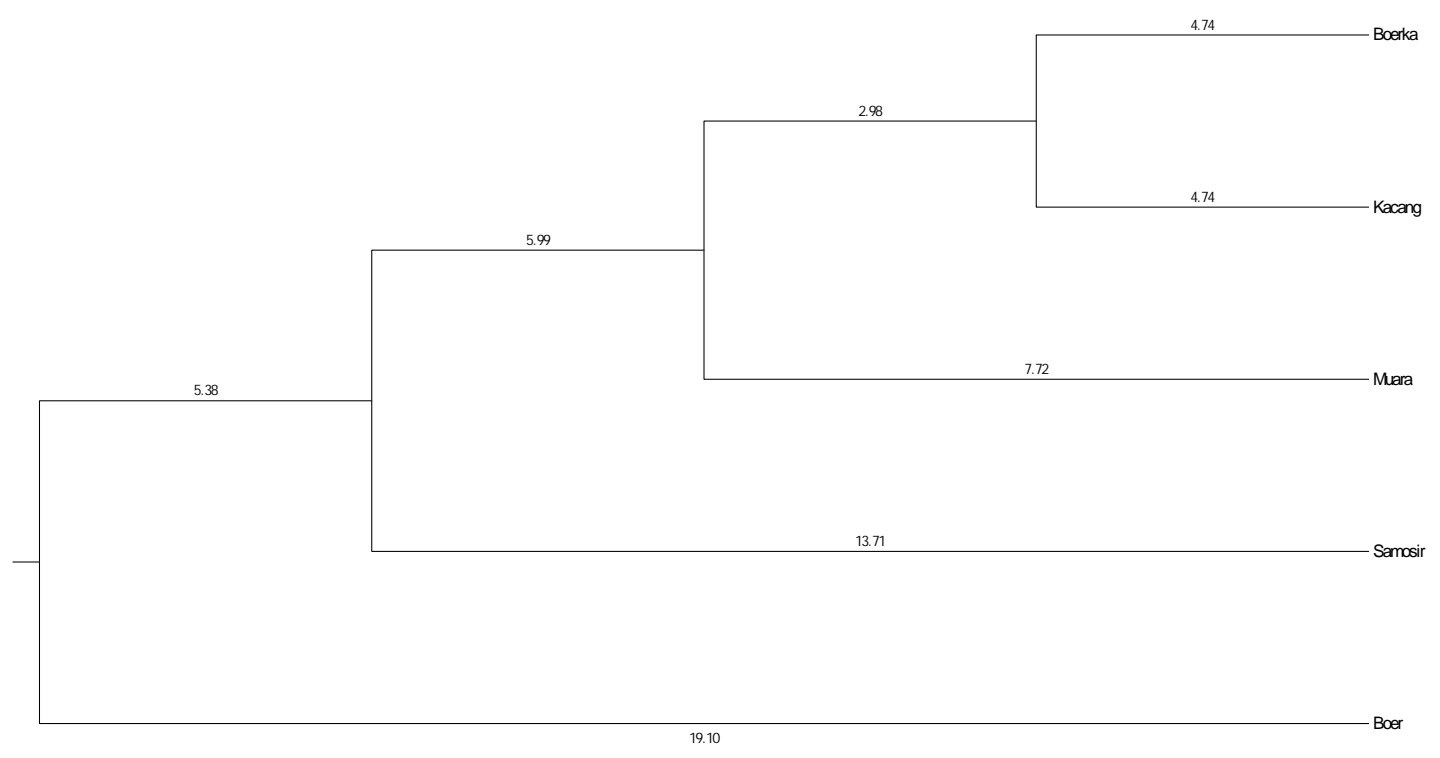

Gambar 2. Dendogram antar bangsa kambing boerka, kacang, muara, samosir dan boer 


\section{KESIMPULAN}

Keragaman ukuran-ukuran tubuh yang tertinggi terdapat pada bangsa kambing Boer dan yang terendah atau lebih seragam terdapat pada bangsa kambing Samosir. Hasil analisis diskriminan dari nilai campuran fenotifik menunjukkan bahwa Kambing Boer (100\%), Muara (100\%), Samosir (100\%), Kacang (87,18\%), Boerka $(86,67 \%)$. Bangsa kambing Boerka dan Kacang memiliki hubungan kekerabatan yang dekat, sedangkan bangsa Kambing Samosir dan Boer memiliki hubungan kekerabatan yang jauh.

\section{DAFTAR PUSTAKA}

Anderson L. 2001. Genetic dissection of phenotypic diversity in farm animals.Nature Rev 2:130-1138.

Blain,D.S. 1992. Genetik Characterisation, surveys and collection of information and genetik. In Daniel.C., Cyaulhun and J.Chiua (eds). Animal gene Bank in Asia FAO, Januari 10-21,1992. Food and agriculture organization of the unised nation. PP: 53-59.

Gunawan A, dan Sumantri C. 2008. Pendugaan nilai campuran fenotipik dan jarak genetik domba garut . J Indon Trop Anim Agric 33(3): 176-185.

Komenes, P.A. 1999. Alfa-casein and beta-lactoglobulin and growth hormone alleles frequencies and genetik distances in Nelore, GYR, Guzera, Caracu, Charolais, Chanchim and Santa Getrudis cattles. Gen Mol Biol 22:539-541.

Kumar., S. Tamura dan M. Nei. 2003. MEGA.Molecular Evolutionary Genetics Analysis.Version 3.0.Institute of Molecular Evolutionary Genetics. The Pennsylvania University, USA.

Lasley, T.J. 1978. Genetic of Livestock Improvement. 3rd Ed. Prentice Hall of India Private Ltd. New Delhi.

Nei, M. 1987. Moleculer Evolutionary Genetic. Columbia University Press. USA.

Salako, A.E., dan L. O Ngere. 2002. Application of multifactorial discriminant analysis in the morphometric structural differentiation of the WAD and Yankasa sheep in the humid southwest Nigeria. Nig. J. Anim. Prod. 29(2):163-7.

Soeparno. 1992. Ilmu dan Teknologi Daging. Gadjah Mada University Press. Yogyakarta.

Walpole, R. 1982. Pengantar Statistika Terjemahan : Sumantri. P.T. Gramedia, Jakarta. 